\title{
ANALYSIS OF BONE METABOLISM IN CHILDREN WITH CYSTIC FIBROSIS
}

\author{
Tatjana Jakovska
}

University Children's Hospital, Medical Faculty, Ss. Cyril and Methodius University, Skopje, Republic of Macedonia

Corresponding author: d-r sci. Tatjana Jakovska, MD, Vodnjanska 17, 1000 Skopje, Macedonia, maretti98@ yahoo.com

\section{ABSTRACT}

One of the most important CF-related conditions is the bone disease, which is nowadays acknowledged as a significant clinical complication of CF. Imbalance between bone formation and degradation in cystic fibrosis (CF) has become an important issue for developing osteopenia. The aim of the study was to assess bone formation and resorption process with bone markers in children with cystic fibrosis (CF). Materials and methods: The study included 35 clinically stable children with CF who regularly attended the Cystic fibrosis center at the University Pediatric Clinic in Skopje, R. Macedonia. The control group was presented with 21 healthy children at the same age. Serum osteocalcin (OC), $\beta$ cross laps, 25OHD and PTH were determined by ELISA assays in the CF group (mean age $8.25 \pm$ SD1.9 y.) and in age-match controls (7.5 \pm 1.9 y.). Results: Vitamin D in the CF group was $(23.83 \pm 10.9 \mathrm{ng} / \mathrm{ml}$ versus $25.6 \pm 11.53$ in the control group, $\mathrm{p}=0.57)$, OC (70.88 $\pm 34.24 \mathrm{ng} / \mathrm{ml}$ v. $100.02 \pm 47.98, \mathrm{p}=0.01) \beta$ crosslaps $(1.35 \pm 0.72 \mathrm{ng} / \mathrm{ml}$ v. $1.54 \pm 0.73$, $\mathrm{p}=0.37)$ and PTH $(37.39 \pm 25.5 \mathrm{pg} / \mathrm{ml}$ v. $36.76 \pm 25.73, \mathrm{p}=0.92)$. In the study, we did not find a significant difference for $25 \mathrm{OHD}$ between $\mathrm{CF}$ and healthy controls. OC in children with CF correlates significantly with the control and indicates a decreased formation rate whereas resorption rate is normal. Conclusion: Our results suggest that bone turnover in CF is impaired in childhood. Serum markers for bone formation can be used for predicting osteopenia in children with CF.

Keywords: cystic fibrosis, osteoporosis, vitamin D deficiency, bone turnover

\section{INTRODUCTION}

Osteopenia and osteoporosis are common in the adult $\mathrm{CF}$ population. Advances in medical care have prolonged the median survival age of patients with cystic fibrosis (CF) from childhood to adulthood. Osteoporosis and failure to maintain body mass are a complication from long survival. [1] Osteoporosis is a metabolic bone disease characterized by low bone mass and micro architectural deterioration of bone tissue, with a consequent increase in bone fragility and susceptibility to fracture risk. The incidence of bone disease in $\mathrm{CF}$ in the world is 30\%. [2] The etiology of osteopenia in CF is multifactorial, including poor nutritional status, repeated episodes of infection and inflammation, altered hormonal status, glucocorticoid use, reduction in physical activities which are necessary to promote bone strength, insufficiency of vitamin D. [3] It can be a result of abnormal turnover, decreased bone formation and increased bone resorption. Patients with $\mathrm{CF}$ have a deficit of liposolubile vitamins (A, D, E and K). Low levels 
of 25OHD are found because of malapsorption, low levels of vitamin D binding protein, reduced sun exposure or rapid catabolism of 25OHD. [4] Peak bone mass is the maximal amount of bone mineral accrued within bone during childhood and adolescence plus the consolidation that continues beyond the attainment of final height. [5] Bone mass reaches a peak between the age of 25 and 35 years. About $40 \%$ of peak bone mass is achieved during puberty. [6] Childhood growth in CF patients represents a critical period for acquisition of bone mass. Genetic potential for peak bone mass is also very important. [7] Longitudinal studies have confirmed that in girls, the greatest increases in bone mass occur between the ages of 12-15 years, compared with 14-17 years in boys. Bone metabolism rates are higher in children than in adults. [8] Puberty is a particularly critical period for mineral accrual, especially for individuals with $\mathrm{CF}$, who often suffer from delayed puberty and lower pubertal growth velocity. Delayed puberty and hypogonadism may impair bone mineral accretion and/or accelerate bone loss. [9] Although more pathological consequences from the bone loss reflect in adulthood, there are many studies about children and pubertal CF patients who cannot achieve half of the bone density compared with their school mates. [10] Bone turnover during growth may be of value in the identification of children who may be at risk for osteoporosis later in life. The aim of the study was to assess bone turnover in children with $\mathrm{CF}$ who regularly visit the $\mathrm{CF}$ center at the University Pediatric Clinic in Skopje, Macedonia.

\section{MATERIALS AND METHODS}

\section{Patients}

The study included 35 clinically stable children with $\mathrm{CF}$ (range 5-12 years) who regularly attended the CF center at the Pediatric Clinic in Skopje. The diagnosis of CF was made by the presence of typical clinical characteristics of CF (chronic respiratory disease and/or pancreatic insufficiency) together with abnormal sweat chloride test ( $>60 \mathrm{moll} / \mathrm{l})$ and/or the presence of two CFTR gene mutations.

The control group included 21 healthy subjects with similar characteristics. They were examined for osteocalcin, ßcrosslaps, PTH,
25OHD, calcium, phosphorus and alkaline phosphatase in serum.

\section{Clinical assessment}

The nutritional status of CF patients was expressed as body mass index (BMI) index for weight and height $\left(\mathrm{kg} / \mathrm{m}^{2}\right)$. Values are compared with standard percentiles for age and sex.

Pulmonary functional tests were measured by Flow Screen-Jaeger Spiro meter. Forced vital capacity $(\mathrm{FVC})$ and forced expiratory volume in one second (FEV1) were analyzed. The values were expressed as percentage of predicted values for sex, age, weight and height.

Cystic fibrosis disease severity was assessed using the Shwachman-Kulczycki (S-K) system, which rates general activity level, pulmonary physical findings, growth and nutrition, and chest radiographic findings. Total S-K scores may range from 20 to 100; low scores representing greater illness severity.

\section{Laboratory measurements}

Calcium, phosphorus, and alkaline phosphatasis were measured in serum at the University Pediatric Clinic in Skopje. Serum osteocalcin (OC), $\beta$ cross laps, 25OHD and PTH were determined by an electrohemiluminiscent method on the automatic immune analyzer elecsys 2010 roche at the University Clinic for Biochemistry in Skopje. Referral values for 25OHD are 1544ng/ml. According to Cystic Fibrosis Foundation levels for $25 \mathrm{OHD}$ in CF patients below30 $\mathrm{ng} / \mathrm{ml}$ are considered insufficient and levels beyond $15 \mathrm{mg} / \mathrm{ml}$ for deficiency.

\section{Bone density measurements}

BMD was measured via dual energy-ray absorptiometry (DXA) scans with spinal scores recorded. They were expressed by $\mathrm{Z}$ or $\mathrm{T}$ scores depending on the age of patients.

Densitometry definition of osteoporosis is accepted by the European Foundation for Osteoporosis and the World Health Organization (WHO) and is the golden standard for the definition of osteoporosis. Osteoporosis is defined as a bone density $<-2$ SD of the mean BMD of the gender-matched, young healthy population. Osteopenia is an intermediate category of reduced bone density defined as a $\mathrm{Z}$ or $\mathrm{T}$ score within -1 SD and -2 SD. 


\section{Statistical analysis}

Results are reported as mean value (M) and standard deviations (SD) for each group. Student's t-test was used for calculating significant differences between the $\mathrm{CF}$ and the control group. Pearson scores were used to determine correlation analysis between BMD and various clinical variables. Statistical significance was defined as $\mathrm{p}<0.05$.

\section{RESULTS}

The study included a total of 35 children with cystic fibrosis and the control group included 21 healthy subjects with similar characteristics.

Table 1. Total number and average age of CF patients and controls

\begin{tabular}{|c|c|c|}
\hline & \multicolumn{2}{|c|}{$5-12$ years old } \\
\hline & CF & control \\
\hline Total number & 35 & 21 \\
\hline years \pm SD & $25 \pm 1.9$ & $5 \pm 1.9$ \\
\hline
\end{tabular}

Table 2. Clinical parameters of CF group

\begin{tabular}{|c|c|c|c|c|c|}
\hline 击 总 & $\sum_{m}$ & $\underbrace{>}_{\text {寽 }}$ & $\underbrace{U}_{i}$ & $\begin{array}{l}z_{1} \\
\text { un }\end{array}$ & $\frac{y}{\dot{n}}$ \\
\hline $\begin{array}{c}5-12 \\
\text { years }\end{array}$ & $19.5 \pm 3.1$ & $84.9 \pm 27.3$ & $92.9 \pm 18.9$ & $8.2 \pm 2.7$ & $89.2 \pm 3.7$ \\
\hline
\end{tabular}

Patients with CF who were included in the study had good nutritional and pulmonary status.

Table 3. Average values for 25OHD, osteocalcin, Bcrosslaps, PTH, calcium, phosphorus and alkaline phosphatase in serum for CF patients and controls

\begin{tabular}{|l|c|c|c|}
\hline & \multicolumn{3}{|c|}{$5-12$ years } \\
\hline & $\mathrm{CF}$ & Controls & $\mathrm{p}$ \\
\hline $25 \mathrm{OHD}(\mathrm{ng} / \mathrm{ml})$ & $23.8 \pm 10.9$ & $25.6 \pm 11.5$ & $\mathrm{NS}$ \\
\hline $\mathrm{OC}(\mathrm{ng} / \mathrm{ml})$ & $70.8 \pm 34.2$ & $100 \pm 47.9$ & $0.01^{*}$ \\
\hline $\mathrm{CTX}(\mathrm{ng} / \mathrm{ml})$ & $1.3 \pm 0.7$ & $1.5 \pm 0.7$ & $\mathrm{NS}$ \\
\hline $\mathrm{PTH}(\mathrm{pg} / \mathrm{ml})$ & $37.3 \pm 25.5$ & $36.7 \pm 25.7$ & $\mathrm{NS}$ \\
\hline $\mathrm{Ca}(\mathrm{mmol} / \mathrm{l})$ & $2.3 \pm 0.1$ & $2.4 \pm 0.08$ & $\mathrm{NS}$ \\
\hline $\mathrm{P}(\mathrm{mmol} / \mathrm{l})$ & $1.6 \pm 0.2$ & $1.6 \pm 0.2$ & $\mathrm{NS}$ \\
\hline $\mathrm{AF}(\mathrm{IE})$ & $261.4 \pm 55.5$ & $215.5 \pm 69.2$ & $\mathrm{NS}$ \\
\hline $\mathrm{BMD} \mathrm{Score}$ & $-0.2 \pm 1.06$ & Not done & NS \\
\hline
\end{tabular}

There was significant difference for the marker of bone formation-osteocalcin $(p=0.01 *)$ between the groups, which indicates that $\mathrm{CF}$ patients have decreased bone formation. Figure 1, shows the correlation $(\mathrm{r}=0.45)$ between osteocalcin and the age of the CF patients; in childhood growth, OC concentrations increased with age.

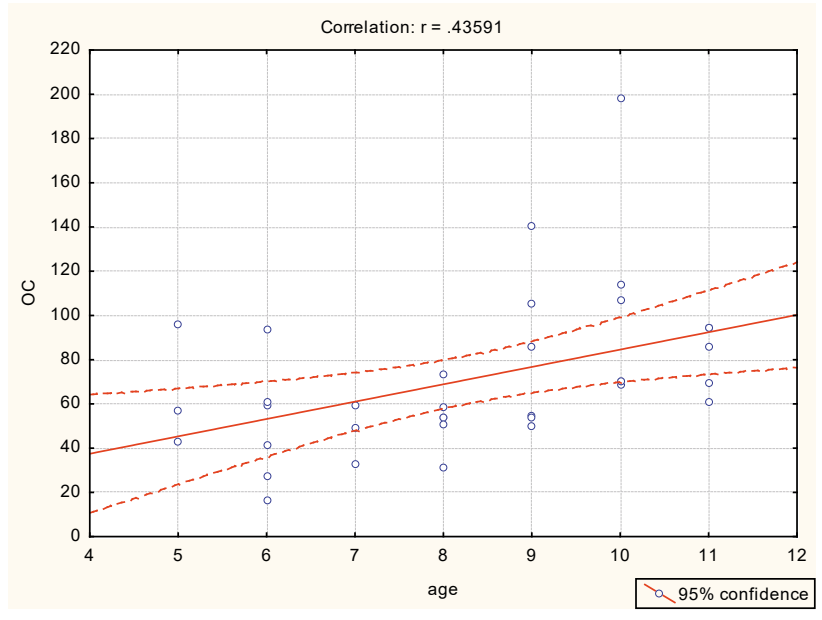

Figure 1. Correlation of $O C$ with the age of $C F$ patients

$28.5 \%$ of the children with $\mathrm{CF}$ who were included in the study, had vitamin D deficiency (serum vitamin $\mathrm{D}<15 \mathrm{ng} / \mathrm{ml}$ ). Reduced bone density had $17 \%$ of CF patients (4 with osteoporosis and 2 with ostepenia).

\section{DISCUSSION}

The bone health is established during infancy, childhood, and adolescence and requires adequate nutrition, body mass, physical activity and hormone production. [1,2] Puberty is the crucial period for gaining adequate peak bone mass accumulation. Decreased peak bone mass accumulation in CF patients is the result of delayed puberty, chronic pulmonary infections and hormonal disbalance. Many studies report that the children and adolescents with $\mathrm{CF}$ do not succeed to achieve adequate bone mass, compared with healthy children in the time of their quick puberty growth. [3, 4] In a study from France in 114 children and adolescents with CF who had good nutritional status and mild lung disease, $34 \%$ had $\mathrm{Z}$ score lower than -1 in the lumbar part of the spine, including patients 6 years old. Similar findings in normal prepubertal children with $\mathrm{CF}$ are reported in stud- 
ies from Grey and al., Bianchi and al. [5, 6] This suggests that the bone disease in the youngest CF patients can develop independently from the nutritional or pulmonary status. [7] In our study, $17 \%$ of $\mathrm{CF}$ patients have reduced bone density. Several studies have shown that bone mass and markers of bone turnover change during adolescence. Levels of bone turnover markers increase during puberty and reach their peak soon after sexual maturity. Studies have shown that $\mathrm{CF}$ patients have pathological bone turnover. That was found for the first time in the study of Grey who found high levels of hydroxyprolin, betacrosslaps and deoxiprolin in urine. [6] Bone turnover markers in CF patients indicate that they suffer from hyperresoption and an inadequate compensation in bone formation even when clinically stable. $[8$, 9, 10] Baroncelli found low circulating concentrations of osteocalcin. [11] In our study we found that children with CF have significantly lower serum osteocalcin $(p<0.01)$. This finding may be an early indication of a problem with bone accretion. The risk from fractures in CF patients starts in late adolescence, and is higher in females. [12, 13, 14] In the meta analysis from 12 studies with a total number of 1055 patients aged 18, 5-32 years, the prevalence of radiological vertebral and no vertebral fractures was $14 \%$. [16] Every vertebral or rib fracture aggravates the clearance of secret from bronchi's what is necessary for the prevention of exacerbations of pulmonary infections.

\section{CONCLUSION}

- Levels of serum markers for bone formation were significantly lower in children with $\mathrm{CF}$ and may contribute to impaired bone turnover.

- Vitamin D deficiency and reduced bone density were present in patients with $C F$ in the study.

- Promoting a healthy life style including physical activity and optimal intake of calcium and vitamin $\mathrm{D}$ may be the best way to achieve maximal peak bone mass.

\section{REFERENCES}

1. Buzzetti R, Salvatore D, Baldo E, et al. An overview of international literature from cystic fibro- sis registries: 1 . Mortality and survival studies in cystic fibrosis. J Cyst Fibros 2009; 8: 229-37

2. Kanis JA. Osteoporosis, revised edition, 1997, Blackwell Healthcare

3. Cashman KD, Seamans K. Bone health, genetics, and personalized nutrition. Genes Nutr. 2007; 2: 47-51

4. Davies JH, Evans AJ, Gregory JW. Bone mass acquisition in healthy children. Arch Dis Child 2005; 90: 373-378.

5. Sermet-Gaudelus I, Souberbielle JC, Ruiz JC, et al. Low bone mineral density in young children with cystic fibrosis. Am J Respir Crit Care Med 2007; 175: 951-7.

6. Grey V, Atkinson S, Drury D, et al. Prevalence of low bone mass and deficiencies of vitamins $\mathrm{D}$ and $\mathrm{K}$ in pediatric patients with cystic fibrosis from 3 Canadian centers. Pediatrics 2008; 122: 1014-20.

7. Bianchi ML, Romano G, Saraifoger S, et al. BMD and body composition in children and young patients affected by cystic fibrosis. J Bone Miner Res 2006; 21: 388-96.

8. Paccou J, Zeboulon N, Combescure C, et al. The prevalence of osteoporosis, osteopenia, and fractures among adults with cystic fibrosis: a systematic literature review with meta-analysis. Calcif Tissue Int 2010; 86: 1-7.

9. Mortensen LA, Chan GM, and all. Bone mineral status in prebubertal children with cystic fibrosis. The Journal of Pediatrics, Volume 136, Number 5

10. Aris RM, Merkel PA, Bachrach LK, et al. Guide to bone health and disease in cystic fibrosis. J Clin Endocrinol Metab 2005; 90: 1888-96. J. Robertson and K. MacDonald, "Prevalence of bone loss in a population with cystic fibrosis," British Journal of Nursing, vol. 19, no. 10, pp. 636-639, 2010.

11. Baroncelli GI, Luca F and all. Bone demineralization in cystic fibrosis: evidence of imbalance between bone formation and degradation. Pediatric Research; Vol.41, No. 3, 1997

12. G. S. Bhudhikanok, M. C. Wang, R. Marcus, A. Harkins, R.B. Moss, and L. K. Bachrach, "Bone acquisition and loss in children and adults with cystic fibrosis: a longitudinal study", Journal of Pediatrics, vol. 133, no. 1, pp. 18-27, 1998.

13. Shead EF, Haworth CS, Gunn E, and all. Osteoclastogenesis during infective exacerbations in patients with cystic fibrosis. Amer. Journal of respiratory and critical care medicine, Vol. 174, 2006.

14. Mora S, Pitukcheewanont P, and all. Biochemical markers of bone turnover and the volume and the density of bone in children at different stages 
of sexual development. Journal of bone and mineral research; Volume 14, Number 10, 1999.

15. Schulze KJ, O’Brien K, and all. Efficiency of calcium absorption is not compromised in clinically stable prepubertal and pubertal girls with cystic fibrosis. Am J Clin Nutr 2003; 78: 110-6.

16. Stephenson A, Jamal S, Dowdell T, et al. Prevalence of vertebral fractures in adults with cystic fibrosis and their relationship to bone mineral density. Chest 2006; 130: 539-44.

17. Elkin SL, Fairney A, Burnett S, et al. Vertebral deformities and low bone mineral density in adults with cystic fibrosis: a cross-sectional study. Osteoporos Int 2001; 12: 366-72.
18. Aris RM, Renner JB, Winders AD, et al. Increased rate of fractures and severe kyphosis: sequelae of living into adulthood with cystic fibrosis. Ann Intern Med 1998; 128: 186-93.

19. Rovner AJ, Stallings VA, Schall JI, et al. Vitamin D insufficiency in children, adolescents, and young adults with cystic fibrosis despite routine oral supplementation. Am J Clin Nutr 2007; 86: 1694-9.

20. Buntain HM, Greer RM, Schluter PJ, et al. Bone mineral density in Australian children, adolescents and adults with cystic fibrosis: a controlled cross sectional study. Thorax 2004; 59: 149-55.

\section{Резиме}

\section{АНАЛИЗА НА КОСКЕНИОТ МЕТАБОЛИЗАМ КАЈ ДЕЦАТА СО ЦИСТИЧНА ФИБРОЗА}

\section{Татјана Јаќовска}

Универзитетска клиника за детски болести, Медицински факултет, Универзитет „Св. Кирил и Методиј“, Скопје, Република Македонија

Една многу важна ЦФ-асоцирана состојба е коскената болест, која во денешно време е призната како значајна клиничка компликација на цистична фиброза (ЦФ). Нерамнотежата меѓу коскеното формирање и разградување кај ЦФ стана многу важно прашање за развојот на остеопенијата. Целта на студијата беше да се процени процесот на коскено формирање и ресорпција преку коскени маркери кај децата со ЦФ.

Материјал и методи: Студијата вклучи 35 клинички стабилни деца со ЦФ, кои редовно го посетуваа Центарот за ЦФ при Клиниката за детски болести во Скопје, Р. Македонија. Серумски остеокалцин (ОЦ), бетакрослапс, 25 ОХД и ПТХ беа анализирани со ЕЛИСА есеи кај ЦФ група $(8,25 \pm 1,9$ г.) и кај соодветна контролна група.

Резултати: Витаминот Д во ЦФ-групата беше $(23,83 \pm 10,9 \mathrm{ng} / \mathrm{ml}$ наспроти $25,6 \pm 11,53$ во контролната група, $\mathrm{p}=0,57)$, остеокалцин $(70,88 \pm 34,24 \mathrm{ng} / \mathrm{ml}$ наспроти $100,02 \pm 47,98, \mathrm{p}=0,01)$ бе-

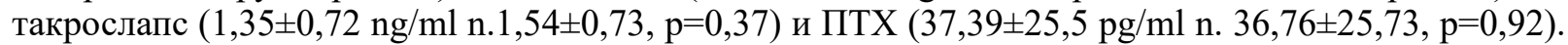
Во студијата не најдовме значајна разлика за витаминот Д меѓу ЦФ и контролната група. ОЦ кај децата со ЦФ корелираше сигнификантно со контролната, укажувајќи на намалено создавање, додека ресорпцијата е нормална.

Заклучок: Нашите резултати укажуваат дека коскениот трновер кај ЦФ е нарушен. Серумските маркери за коскено создавање може да се употребат за предвидување на остеопенија кај ЦФ-пациенти.

Клучни зборови: цистична фиброза, остеопороза, витамин Д дефицит, коскен трновер 